\title{
A Visualized Analysis of Literary Translation in China $(2000-2017)^{*}$
}

\author{
Lu Zhou \\ School of English Studies \\ Jiangxi College of Foreign Studies \\ Nanchang, China
}

\author{
Yue Zhao \\ School of English Studies \\ Jiangxi College of Foreign Studies \\ Nanchang, China
}

\author{
Yuanyuan Xie \\ School of English Studies \\ Jiangxi College of Foreign Studies \\ Nanchang, China
}

\begin{abstract}
This article presents an analysis of articles from 2000 to 2017 on the studies of literary translation from CNKI (China National Knowledge Internet) database of the three major journals related to translation studies in China. Statistical analysis of document and information visualization software tool of Cite Space has been applied together. To demonstrate the hotspots, the high impact authors, institutions, most cited articles and the high frequency keywords of literary translation studies in China, visualized pictures that show the basic situation of domestic researches from year 2000 to 2017 objectively are utilized. All these help to describe the panorama of the coming trend of literary translation development and could hopefully provide references for future endeavor in this field.
\end{abstract}

Keywords-literary translation; visualized analysis; CiteSpace

\section{INTRODUCTION}

Literary translation has a long history in China, dating back to the Song of Yue People in Liu Xiang's work Shuo Yuan (Garden of Anecdotes) in the 1st century BC. In the west, it can be traced back to about 250 BC in Roman, when Livius Andronicus translated Homer's epic Odyssey in Latin. Since the existence of literary translation, people have never stopped thinking and exploring it. Many scholars even write books on literary translation. Different scholars have put forward a lot of thinking and discussion on literary translation from different angles due to different research purposes and have drawn various conclusions.

This study collects data from CNKI (China National Knowledge Internet) database. It analyzes high influence authors, institutions, literature and the high frequency keywords by CiteSpace, and expounds the domestic research status of literary translation as well as the reasons behind the phenomenon, which help to describe the coming trend of literary translation development and could hopefully provide

*Sponsored by Humanities and Social Science Research Project in Jiangxi Province (Project No. YY162015, No. YY17213) references for future endeavor in this field.

\section{DATA COLLECTION AND ANALYSIS}

\section{A. Data Source}

This article takes the three high influence Chinese translation journals from CNKI as the data source and the research samples, which is sorted according to the compound impact factor and the comprehensive impact factor as shown in "Table I".

The data source is from Chinese Translators Journal, Shanghai Journal of Translators and Chinese Science \& Technology Translators Journal, which are mainly on translation studies. For spelling convenience, they are all shorted in the tables as CTJ, SJT, CSTTJ respectively. The selection criteria are the names, sponsors, compound impact factors and comprehensive impact factors, etc.

TABLE I. THREE HIGH-IMPACT TRANSLATION JOURNALS INCLUDED BY CNKI (2000- 2017)

\begin{tabular}{|c|c|c|c|}
\hline Journal & Sponsor & $\begin{array}{l}\text { Compound } \\
\text { Impact } \\
\text { Factor } \\
\end{array}$ & $\begin{array}{l}\text { Comprehensive } \\
\text { Impact Factor }\end{array}$ \\
\hline CTJ & $\begin{array}{l}\text { China International } \\
\text { Publishing Group; } \\
\text { Translators } \\
\text { Association } \\
\text { China }\end{array}$ & 2.242 & 1.407 \\
\hline SJT & $\begin{array}{l}\text { Shanghai Science } \\
\text { and Technology } \\
\text { Translation Society }\end{array}$ & 1.329 & 0.877 \\
\hline CSTTJ & $\begin{array}{l}\text { Science and } \\
\text { Technology } \\
\text { Translators' } \\
\text { Association of } \\
\text { Chinese Academy of } \\
\text { Sciences }\end{array}$ & 0.920 & 0.399 \\
\hline
\end{tabular}




\section{B. Retrieval Mode}

Based on CNKI retrieval data source, with retrieve theme "translation" and "literary translation" respectively for data collection and comparison, the article searches from 2000 to 2017. With retrieve theme word "translation", 2641 papers are retrieved in Chinese Translators Journal, 1170 in Shanghai Journal of Translators, 1163 in Chinese Science \& Technology Translators Journal and a total of 4974 articles. With retrieve theme word "literary translation", the corresponding number are 374, 72, 18 and 464. By excluding book reviews, contributions, memoirs and other irrelevant literature, the valid literature number is 409. The data renewal date is up to April 15, 2018. A comparative analysis of the three representative journals can be obtained in "Table II".

TABLE II. NUMBER AND PROPORTION OF LITERARY TRANSLATION (2000- 2017)

\begin{tabular}{|c|c|c|c|c|}
\hline \multirow{3}{*}{$\begin{array}{l}\text { Journal } \\
\text { CTJ }\end{array}$} & \multicolumn{3}{|c|}{ Paper Number } & \multirow{3}{*}{$\begin{array}{c}\begin{array}{c}\text { Proportion of } \\
\text { Literary } \\
\text { Translation }\end{array} \\
80.60 \% \\
\end{array}$} \\
\hline & \multirow{2}{*}{$\begin{array}{c}\text { Search Term: } \\
\text { Translation }\end{array}$} & \multicolumn{2}{|c|}{$\begin{array}{c}\text { Search Term: } \\
\text { Literary Translation }\end{array}$} & \\
\hline & & 374 & 331 & \\
\hline SJT & 1170 & 72 & 70 & $15.52 \%$ \\
\hline CSTTJ & 1163 & 18 & 8 & $3.88 \%$ \\
\hline Total & 4974 & 464 & 409 & $9.33 \%$ \\
\hline
\end{tabular}

As shown in "Table II", proportion of papers on literary translation in Chinese Translators Journal is $80.60 \%, 15.52 \%$ in Shanghai Journal of Translators and $3.88 \%$ in Chinese Science \& Technology Translators Journal. Further analyzing the data, the total proportion of "literary translation" in the three high-impact translation journals accounted for $9.33 \%$ of the total proportion of "translation", from which a serious unbalance of the proportion of literary translation can be seen. On the one hand, it reflects the lack of attention paid to literary translation studies in the translation field, on the other hand, it also shows the weakness and deficiency of literary translation theory. Based on data information collection, the article generates a visual map and expands the quantitative description and qualitative analysis of the literary translation studies in China from 2000 to 2017.

\section{Data Analysis Tool}

The data analysis tool used in this study is CiteSpace developed by professor CHEN Chaomei of Drexel University. The tool integrates scientometrics information visualization methods, literature metrology and data mining algorithm, which can set up nodes relevance between quotation and co-citation and map information visualization network. It can even set up an interactive visualization tool in citation data according to the extracted model.

The knowledge map and visual analysis of the software are widely used in the analysis and prediction of the research frontiers and trends of the natural sciences. Its application in social science is rare. Applying CiteSpace to translation studies began in January 2014, when FENG Jia, WANG Kefei, LIU Xia from Beijing Foreign Studies University published in Technology Enhanced Foreign Language Education titled Emerging Trends in Translation Studies (1993-2012): A Scientometric Analysis in CiteSpace.

\section{VISUAL ANALYSIS OF THE CURRENT MAPPING KNOWLEDGE DOMAIN IN DOMESTIC LITERARY} TRANSLATION STUDIES

The article puts in the bibliographic records of the 409 papers, including titles, authors, keywords, abstract, references and save in the form of text file. By combining CiteSpace and the traditional bibliometrical method for data statistics and mapping knowledge analysis, it interpretates the status and research trends for domestic literary translation research from multi-angle directions.

\section{A. Analysis of Authors and Research Institutes}

1) High impact author analysis: The study of the high impact authors and their research practice helps to understand the domestic research trends and development directions for literary translation. The paper number can reflect the authors' scientific research productivity and academic influence.

TABLE III. High-YIELD AUTHOR LiST (More THAN 2 ARTIClES) (2000-2017)

\begin{tabular}{|l|l|l|l|}
\hline Ranking & \multicolumn{1}{|c|}{ Author } & $\begin{array}{c}\text { Paper } \\
\text { Number }\end{array}$ & \multicolumn{1}{|c|}{ Institute } \\
\hline 1 & $\begin{array}{l}\text { XU } \\
\text { Yuanchong }\end{array}$ & 6 & Peking University \\
\hline 2 & $\begin{array}{l}\text { WANG } \\
\text { Dongfeng }\end{array}$ & 4 & Sun Yat-sen University \\
\hline 3 & SUN Zhili & 3 & $\begin{array}{l}\text { PLA University of Foreign } \\
\text { Language }\end{array}$ \\
\hline 4 & $\begin{array}{l}\text { ZENG } \\
\text { Lisha }\end{array}$ & 2 & $\begin{array}{l}\text { Guangdong University of } \\
\text { Foreign Studies }\end{array}$ \\
\hline 5 & YANG Liu & 2 & Nanjing University \\
\hline 6 & $\begin{array}{l}\text { JIANG } \\
\text { Qiuxia }\end{array}$ & 2 & Nanjing University \\
\hline
\end{tabular}

"Table III" is the list of authors who have published more than 2 literary translation papers in the three translation journals from 2000 to 2017. They are highly productive authors in the field of literary translation studies in China.

In the high yield authors list, XU Yuanchong, from Peking University, with 6 papers ranks the first place, which shows his rich research achievements. It is followed by WANG Dongfeng from Sun Yat-sen University with four papers. YANG Liu and JIANG Qiuxia from Nanjing University published four articles, which highlights the inheritance of literary translation studies in the university. The total number of SUN Zhili from PLA University of Foreign Language is 3, and ZENG Lisha from Guangdong University of Foreign Studies is 2.

These scholars have great influence in the development of Chinese literary translation, and their research achievement of translation theory and practice are very rich. They are the backbone of literary translation studies.

2) Research institute analysis: The data is imported into CiteSpace, and the distribution of Chinese literary 
translation from 2000 to 2017 is statistically analyzed, as shown in "Table IV" and "Fig. 1".

TABLE IV. RESEARCH INSTITUTE LiST (MORE THAN3 ARTICLES) (2000-2017)

\begin{tabular}{|l|l|l|}
\hline Ranking & \multicolumn{1}{|c|}{$\begin{array}{c}\text { Research } \\
\text { Institute }\end{array}$} & \multicolumn{1}{c|}{$\begin{array}{c}\text { Paper } \\
\text { Number }\end{array}$} \\
\hline 1 & Nanjing University & 10 \\
\hline 2 & Peking University & 9 \\
\hline 3 & $\begin{array}{l}\text { Shanghai International Studies } \\
\text { University }\end{array}$ & 6 \\
\hline 4 & PLA University of Foreign Language & 5 \\
\hline 5 & $\begin{array}{l}\text { Guangdong University of Foreign } \\
\text { Studies }\end{array}$ & 5 \\
\hline 6 & Sun Yat-sen University & 4 \\
\hline 7 & Beijing Foreign Studies University & 3 \\
\hline
\end{tabular}

The top 7 institutions in the list are Nanjing University, Peking University, Shanghai International Studies University, PLA University of Foreign Language, Guangdong University of Foreign Studies, Sun Yat-sen University and Beijing Foreign Studies University. These 7 universities are the key national ones or foreign language ones. They are all authorized centers for doctoral degree for foreign language and literature and translation, many of which are centers for post-doctoral studies for foreign language and literature, with strong ability of academic research. They are the major force in translation studies.

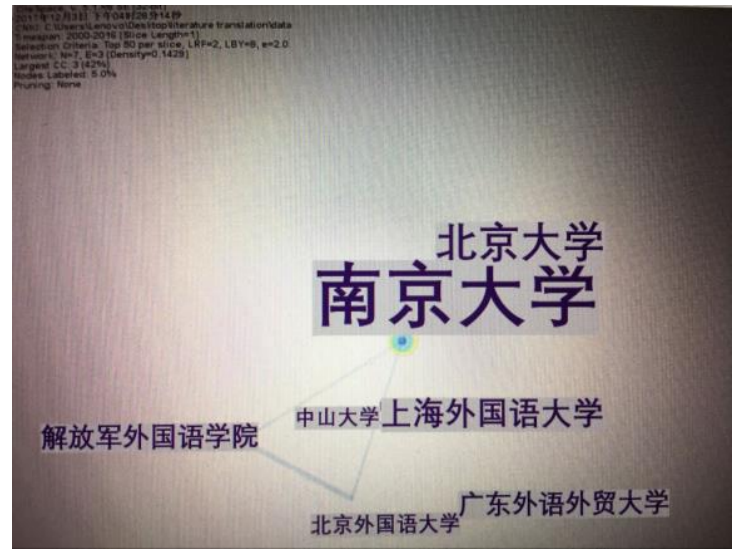

Fig. 1. Active research institute network (2000-2017).

\section{B. High Impact Literature Analysis}

Cited frequency is a form of peer recognition scholars get within a field, which reflects the trust and recognition of scholars in the discipline. It manifests the role papers play in the discipline development. The research achievements of the highly cited authors also reflect and form a core in a field.

In this study, the citation frequency is used as the evaluation criterion, and the high impact literature is statistically analyzed. Table $\mathrm{V}$ shows the titles of the article, the authors' name, the authors' institutes, the cited frequency and the number of downloads of the first 10 articles in the field of domestic literary translation from 2000 to 2017.

The 10 high impact literatures are as follows:

- China's Literary Translation: from Domestication to Foreignization
- Film Translation: An Increasingly Important Field of Translation

- About Domestication and Foreignization

- The Translator's Subjectivity: A Hermeneutic Exposition

- Reception Aesthetics of Literary Translation

- Some More Words on the Strategy of Literary Translation

- Revisiting the Subject of Literary Translation

- Translation into Chinese of Film Scripts and Scripts of TV Drama Series: Four Main Conflicting Demands

- On the Translation of Children's Literature

- New Translation Theories in the New Century

TABLE V. High IMPACT LiterATURE List (2000-2017)

\begin{tabular}{|c|c|c|c|c|}
\hline $\begin{array}{l}\text { Literature } \\
\text { No. }\end{array}$ & Author & $\begin{array}{l}\text { Research } \\
\text { Institute }\end{array}$ & $\begin{array}{c}\text { Citation } \\
\text { Time }\end{array}$ & $\begin{array}{c}\text { Download } \\
\text { Time }\end{array}$ \\
\hline 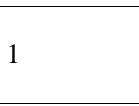 & SUN Zhili & $\begin{array}{l}\text { PLA University } \\
\text { of } \quad \text { Foreign } \\
\text { Language }\end{array}$ & 2004 & 16321 \\
\hline 2 & $\begin{array}{l}\text { QIAN } \\
\text { Shaochang }\end{array}$ & $\begin{array}{l}\text { Shanghai } \\
\text { International } \\
\text { Studies } \\
\text { University }\end{array}$ & 1691 & 15967 \\
\hline 3 & $\begin{array}{l}\text { WANG } \\
\text { Dongfeng }\end{array}$ & $\begin{array}{l}\text { Sun Yat-sen } \\
\text { University }\end{array}$ & 1379 & 10813 \\
\hline 4 & $\begin{array}{l}\text { TU } \\
\text { Guoyuan, } \\
\text { ZHU } \\
\text { Xianlong }\end{array}$ & $\begin{array}{l}\text { Central South } \\
\text { University }\end{array}$ & 1162 & 8939 \\
\hline 5 & MA Xiao & $\begin{array}{l}\text { Wuhan } \\
\text { University }\end{array}$ & 611 & 5984 \\
\hline 6 & SUN Zhili & $\begin{array}{l}\text { PLA University } \\
\text { of } \quad \text { Foreign } \\
\text { Language }\end{array}$ & 500 & 4453 \\
\hline 7 & $\begin{array}{l}\text { YANG } \\
\text { Wuneng }\end{array}$ & $\begin{array}{l}\text { Sichuan } \\
\text { University }\end{array}$ & 487 & 3148 \\
\hline 8 & $\begin{array}{l}\text { ZHAO } \\
\text { Chunmei }\end{array}$ & CCTV & 460 & 3654 \\
\hline 9 & XU Derong & $\begin{array}{l}\text { Ocean } \\
\text { University of } \\
\text { China }\end{array}$ & 438 & 4881 \\
\hline 10 & $\begin{array}{l}\text { XU } \\
\text { Yuanchong }\end{array}$ & $\begin{array}{l}\text { Peking } \\
\text { University }\end{array}$ & 314 & 2460 \\
\hline
\end{tabular}

In "Table V", SUN Zhili from PLA University of Foreign Language, whose China's Literary Translation: from Domestication to Foreignization with citation time of 2004 ranked first, Some More Words on the Strategy of Literary Translation with 500 citation time is in the sixth place. It can be seen that SUN Zhili has both theory and practice studies in literary translation. In addition, XU Yuanchong from Peking University, WANG Dongfeng from Sun Yat-sen University is also in the high-yield authors and highly cited authors list. They are prominent scholars in literary translation field. They have carried out theoretical analysis and practical summary of domestic literary translation studies and played a major role in promoting the development of Chinese literary translation. 
Literature 1 is an overview of Chinese literary translation, and it is believed that foreignization translation will become the main strategy of Chinese literary translation. Translation studies and practices cannot avoid the influence of cultural factors, so there has always been a struggle between domestication and foreignization in translation. From CNKI, it is found that LIU Yingkai's Domestication: the Wrong Road of Translation is the first scholar to bring up domestication and foreignization from the late 1980s. After that, GUO Jianzhong wrote that domestication and foreignization have their own missions and existence values, hoping to reconcile the two. Literature 1 has a strong point of view and is elaborated discussed, both make it an important cited literature in the dispute between domestication and foreignization, and also provides an important reference for the study of translation strategies. From the perspective of the hermeneutics of modern philosophy, literature 4 demonstrates the rationality of the existence of misreading in translation, and emphasizes the objectivity of the translator's subjectivity.

These literary translation studies are highly influential literature, and most of them belong to translation strategy research, which is inseparable from the practical nature of translation activity. Translation strategy is an important part in translation activities and its importance is self-evident. Domestication, foreignization and subjectivity in translation strategies are still the focus in literary translation. Other literatures related to aesthetics, film, children's literature, etc., partly due to the unique perspectives and path-breaking ideas, also become the high-impact ones.

\section{Hot Keywords Analysis}

The capture of research hotspot is helpful to understand the core subjects and development trends of the discipline in a certain period. The keyword of high quality article is the extraction of core content of the article. In the literature of a certain field, repeated keywords are the research focus of this field. To teasing hot topics and transition of literary translation, this article uses CiteSpace 5 to extract the keywords and draw the knowledge mapping of literary translation between 2000 and 2017, as shown in "Fig. 2".

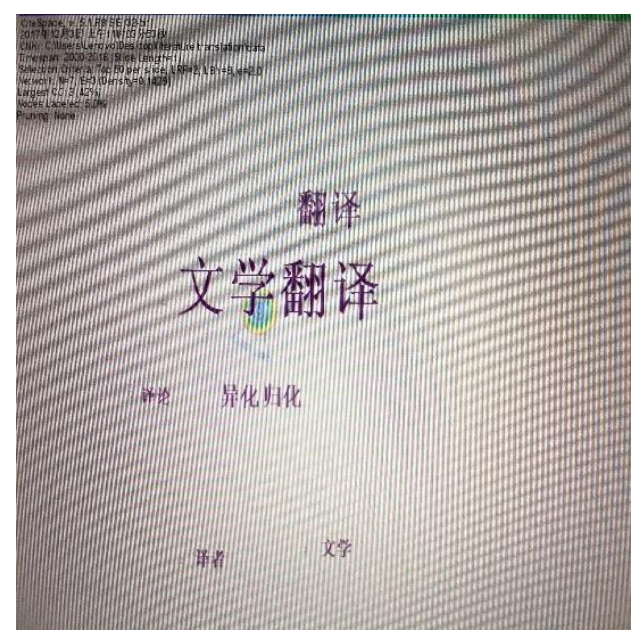

Fig. 2. High frequency key words in literary translation.
"Fig. 2" is a knowledge map puts literary translation as the center and displays cluster nodes and headwords, which is based on the high frequency keywords co-occurrence network. The larger the node, the more frequency of the keyword. The clustering of the subject headings displays research frontier. To some extent, the high frequency keywords such as "literary translation", "translation", "foreignization", "domestication", "literature", "translator", "translation theory", etc. represents hot issues of common concern in literary translation from 2000 to 2017.

First of all, in the period of 2000 to 2017, as keywords, the occurrence frequency of "literary translation" is 42 , "translation" is 9, "alienation" and "naturalization" are both 3 . It can be seen that the research focus on translation is methods and strategies in recent years. Translation methods and strategies is an indispensable part of literary translation, because the quality of literary works translation is closely related to the development of literary translation, and the quality of the literary works is a powerful guarantee for sustainable development of literary translation, should be a research focus in literary translation.

Secondly, according to Fig. 2, the occurrence frequency of "literature", "translator", "translation theory" as keywords is 2, which shows "translator" and "translation theory" has aroused concern from the literary translation experts. For the consciousness awakening of translation theory in our country, translation theory research gradually become another important research object. Many scholars introduce foreign translation theory and carry out creative research. Although the study of "translators" is slightly less extensive, it still occupies a considerable position in the field of literary translation, which is of particular concern.

\section{CONCLUSION}

With the aid of this scientific metrology software CiteSpace, this research analyzes the documents from the three translation journals from 2000 to 2017. It finds that translation strategies receive special attention, domestication and foreignization are also rising hotspots recently. In addition, the translation theory, the translator and other topics have gradually attracted the attention of scholars. However, although using CiteSpace to draw knowledge map of authors, research institutes, hot spot topics for literature from the three translation journals from 2000 to 2017, there are still some problems to be further solved in this article. Firstly, for CNKI limitation, literature co-citation cannot be collected. Secondly, the selection of periodicals is limited. Thirdly, it does not analyze all the translation literatures listed and hot spots. In later researches, for further enriching literary translation theory and practice, it is necessary to choose longer periods, to expand the range of journal selection, such as CSSCI, to reselect database, such as Web of Science for further macro analysis and to select more research hotspots to do case analysis. 


\section{REFERENCES}

[1] FENG Jia, WANG Kefei, LIU Xia. Emerging Trends in Translation Studies (1993-2012): A Scientometric Analysis in CiteSpace[J]. Technology Enhanced Foreign Language Education, 2014(1): 11-20.

[2] GUO Jianzhong. Cultural Factors in Translation: Adaption and Alienation [J].Journal of Foreign Languages, 1998(2):12-18.

[3] LI Hongman. The Cutting-edge Research Interests and Topics of International Translation Studies: A Visualized Analysis of Relevant SSCI Data(2008-2012) [J]. Chinese Translators Journal, 2014(2):2126.

[4] LIU Yingkai. Domestication: the Wrong Road of Translation [J]. Modern Foreign Languages, 1987(2):58-64.

[5] MA Xiao. Reception Aesthetics of Literary Translation [J]. Chinese Translators Journal, 2000(2):47-51.

[6] QIAN Shaochang. Film Translation: An Increasingly Important Field of Translation[J]. 2000(1):61-65.

[7] SUN Zhili. China's Literary Translation: from Domestication to Foreignization [J]. Chinese Translators Journal, 2002(1):40-44.

[8] SUN Zhili. Some More Words on the Strategy of Literary Translation [J]. Chinese Translators Journal, 2003(1):48-51.

[9] TU Guoyuan, ZHU Xianlong. The Translator's Subjectivity: A Hermeneutic Exposition [J]. Chinese Translators Journal, 2003(6): 8-14

[10] WANG Dongfeng. About Domestication and Foreignization [J]. Chinese Translators Journal, 2002(5):24-26.

[11] XU Derong. On the Translation of Children's Literature [J]. Chinese Translators Journal, 2004(6):33-36.

[12] XU Yuanchong. New Translation Theories in the New Century [J]. Chinese Translators Journal, 2000(3):2-6.

[13] YANG Wuneng. Revisiting the Subject of Literary Translation[J]. Chinese Translators Journal, 2003(3):10-13.

[14] ZHAO Chunmei. Translation into Chinese of Film Scripts and Scripts of TV Drama Series: Four Main Conflicting Demands [J]. Chinese Translators Journal, 2002(4): 49-51. 